\title{
Manajemen Produksi Caisim Organik dengan Aspek Khusus Pemulsaan di Yayasan Bina Sarana Bakti, Cisarua, Bogor, Jawa Barat
}

\section{Management of Organic Caisim Production with Special Aspects of Mulching in Yayasan Bina Sarana Bakti, Cisarua, Bogor, Jawa Barat}

\author{
Delima Ragil Kartika, Anggi Nindita* dan Ade Wachjar
}

\author{
Departemen Agronomi dan Hortikultura, Fakultas Pertanian, Institut Pertanian Bogor \\ (Bogor Agricultural University), J1. Meranti, Kampus IPB Darmaga, Bogor 16680, Indonesia \\ Telp. \& Faks.62-251-8629353 e-mail agrohort@apps.ipb.ac.id \\ *Penulis Korespondensi : angginindita@yahoo.com
}

Disetujui : 9 Mei 2018 / Published Online 2 Januari 2019

\begin{abstract}
Caisim (Brassica juncea L.) is one of vegetables that consumed to meet the needs of vitamins, minerals, fiber, and protein. Caisim are included in the vegetables most often consumed by the people of Indonesia. Caisim cultivation requires good techniques and handling to meet both quantity and quality. The research was aimed to study the effect of mulching on the production of caisim plants organically in Yayasan Bina Sarana Bakti. The research was conducted from February to June 2017 at Yayasan Bina Sarana Bakti, Cisarua, Bogor, West Java. Primary data was obtained through observation of vegetative phase variables include plant height, leaf number, leaf length, and leaf width. The variables observed at post-harvest include weight of root, root weight, weight per plant, leaf number, leaf weight, number of leaves mechanically damaged, leaf weight mechanical damage, number of leaves damaged by pest, leaf weight loss due to pest, number of old leaves, old leaf weight, and weed population were observed at the time after harvesting of ten sample plants in each plot. Treatment of mulching Tithonia sp. elucidated the highest results compared with control and other mulch treatments on the variables in the vegetative phase. The experiment result of mulch from grass, mulch from banana pseudostem, and mulch from Tithonia sp., was significantly suppress the weed population in the bed.
\end{abstract}

Keywords: agronomy, Brassica juncea L., crop production, organic mulch.

\begin{abstract}
ABSTRAK
Caisim (Brassica juncea L.) merupakan salah satu jenis sayuran yang dikonsumsi untuk memenuhi kebuthan vitamin, mineral, serat, dan protein. Sayuran ini termasuk ke dalam sayuran yang paling sering dikonsumsi oleh masyarakat Indonesia. Budidaya caisim memerlukan teknik dan penanganan yang baik untuk mencukupi kuantitas maupun kualitasnya. Tujuan kegiatan penelitian adalah mempelajari dan mengetahui pengaruh pemulsaan terhadap produksi tanaman caisim secara organis di Yayasan Bina Sarana Bakti. Kegiatan penelitian dilaksanakan pada bulan Februari sampai dengan Juni 2017 di Yayasan Bina Sarana Bakti, Cisarua, Bogor, Jawa Barat. Data primer didapatkan melalui pengamatan peubah fase vegetatif meliputi tinggi tanaman, jumlah daun, panjang daun, dan lebar daun. Peubah yang diamati pada saat pasca panen meliputi bobot brangkasan, bobot akar, bobot per tanaman, jumlah daun rompesan, bobot daun rompesan, jumlah daun rusak mekanis, bobot daun rusak mekanis, jumlah daun rusak akibat OPT, bobot daun rusak akibat OPT, jumlah daun tua, bobot daun tua, dan populasi gulma yang diamati pada saat setelah panen terhadap sepuluh tanaman contoh pada masing-masing petak. Perlakuan pemberian mulsa Tithonia sp. cenderung menunjukkan hasil tertinggi dibandingkan dengan kontrol dan perlakuan mulsa lainnya terhadap peubah pada fase vegetatif. Pemberian mulsa baik mulsa rumput, mulsa gedebong pisang, maupun mulsa Tithonia sp., secara nyata mampu menekan populasi gulma dalam bedengan.
\end{abstract}

Kata kunci : agronomi, Brassica juncea L., mulsa organik, produksi tanaman. 


\section{PENDAHULUAN}

Sayur merupakan salah satu bahan makanan yang dikonsumsi oleh masyarakat sebagai sumber serat, protein, vitamin dan mineral. Kandungan gizi yang terdapat dalam sayuran penting dalam pembentukan sel- sel di dalam tubuh, serta menjaga kesehatan dan kebugaran tubuh meskipun jumlah yang dibutuhkan sedikit. Konsumsi sayuran organik belakangan ini telah menjadi trend dikalangan masyarakat (AOI, 2015). Masyarakat mulai mengurapenelitianngi konsumsi sayuran yang diproduksi secara konvensional dan beralih ke sayuran organik. Kesadaran mengenai pentingnya penerapan pola hidup sehat menjadi salah satu alasan memilih bahan pangan yang aman untuk dikonsumsi seperti sayuran organik yang diproduksi dengan kandungan residu bahan kimia berbahaya yang minimum.

Budidaya sayuran organis di Indonesia pertama kali diperkenalkan oleh Yayasan Bina Sarana Bakti (YBSB) di Cisarua, Bogor, Jawa Barat sejak tahun 1984 (Jahroh, 2010). Komoditas yang dibudidayakan secara organis di YBSB beragam jenisnya contohnya adalah caisim. Caisim (Brassica juncea L.) atau yang biasa dikenal dengan sawi hijau merupakan salah satu jenis sayuran yang paling sering dikonsumsi oleh masyarakat. Data Statistik Konsumsi Pangan (Kementan, 2015) menunjukkan bahwa tahun 2015 konsumsi sawi hijau sebesar 2086 kg kapita $^{-}$ 1 tahun $^{-1}$, sedangkan di YBSB permintaan caisim tergolong cukup tinggi yaitu $80 \mathrm{~kg}$ bulan $^{-1}$. Ini menjadikan caisim termasuk ke dalam daftar dua puluh komoditas utama yang diusahakan di YBSB.

Teknik budidaya menjadi faktor penting dalam usaha pemenuhan kebutuhan sayuran caisim. Penerapan teknik yang tepat dari mulai penyediaan benih hingga penanganan pasca panen dapat menghasilkan produk yang optimum baik dari segi kuantitas maupun kualitasnya. Pemulsaan merupakan salah satu kegiatan pemeliharaan yang memengaruhi kualitas dan kuantitas caisim. Kehilangan hasil yang diakibatkan oleh organisme pengganggu tanaman (OPT) dapat diminimalisir dengan pemberian mulsa (Yulianingrum et al., 2016). Tujuan khusus penelitian adalah mempelajari dan mengetahui pengaruh pemulsaan terhadap produksi tanaman caisim secara organis.

\section{BAHAN DAN METODE}

Kegiatan penelitian dilaksanakan di Yayasan Bina Sarana Bakti, Cisarua, Bogor, Jawa
Barat. Pelaksanaan penelitian berlangsung selama 4 bulan yaitu mulai dari bulan Februari sampai dengan Juni 2017. Beberapa tahap yang dilakukan dalam kegiatan penelitian yaitu satu bulan sebagai karyawan harian lepas (KHL), dua bulan sebagai pendamping kepala kebun, dan satu bulan sebagai pendamping kepala bagian produksi. Kegiatan yang dilakukan sebagai KHL yaitu melakukan persiapan media tanam, penyemaian, penyiapan lahan, penanaman, pemeliharaan, pemanenan, dan penanganan pasca panen primer. Tahap selanjutnya sebagai pendamping mandor meliputi pembuatan rencana panen (R-panen), rencana tanam (R- tanam), dan rencana semai (R-semai), pengawasan kebun, pengawasan penanaman, pengawasan pemeliharaan, pengawasan pemanenan, serta pengawasan tenaga kerja. Sedangkan saat menjadi pendamping kepala bagian produksi kegiatan yang dilakukan meliputi kegiatan perencanaan produksi, perhitungan seluruh kebutuhan produksi, evaluasi prestasi tenaga kerja, monitoring kegiatan produksi, perhitungan biaya operasional, dan pembuatan laporan rutin bulanan.

Pengamatan dan pengumpulan data dilakukan selama kegiatan penelitian berlangsung untuk memperoleh dua jenis data yaitu data primer dan data sekunder. Data primer diperoleh dengan metode langsung yaitu berupa praktik kerja di lapangan, pengamatan peubah pada aspek khusus yang diamati, dan wawancara langsung dengan karyawan di kebun atau staff terkait dengan kegiatan produksi. Data sekunder diperoleh dengan metode tidak langsung yaitu dengan mempelajari arsip manajemen perusahaan, dokumentasi lapang, serta berbagai literatur lain yang terkait.

Data primer diperoleh dengan menggunakan rancangan kelompok lengkap teracak (RKLT) satu faktor yaitu jenis mulsa organik. Jenis mulsa organik terdiri atas empat taraf perlakuan yaitu M0 (tanpa mulsa), M1 (mulsa dari rumput lunak), M2 (mulsa dari kedebong pisang), M3 (mulsa dari daun Tithonia sp.). Setiap perlakuan diulang sebanyak tiga kali sehingga terdapat dua belas satuan percobaan. Masing-masing petak percobaan berukuran $1 \mathrm{~m}$ x $5 \mathrm{~m}$ dengan sepuluh tanaman contoh yang diamati sehingga terdapat 120 tanaman contoh.

Data primer didapatkan melalui pengamatan beberapa peubah yaitu pada fase vegetatif meliputi tinggi tanaman, jumlah daun, panjang daun, dan lebar daun. Peubah pada fase vegetatif diamati selama masa vegetatif yaitu 1 MSP, 2 MSP, dan 3 MSP yang dilakukan terhadap sepuluh tanaman contoh pada setiap petak. Peubah yang diamati pada saat pasca panen 
meliputi bobot brangkasan, bobot akar, bobot per tanaman, jumlah daun rompesan, bobot daun rompesan, jumlah daun rusak mekanis, bobot daun rusak mekanis, jumlah daun rusak akibat OPT, bobot daun rusak akibat OPT, jumlah daun tua, bobot daun tua, dan populasi gulma yang diamati pada saat setelah panen terhadap sepuluh tanaman contoh pada masing-masing petak.

Data dan informasi yang diperoleh dianalisis secara deskriptif kuantitatif. Data primer yang diperoleh dengan cara dianalisis dengan uji$\mathrm{F}$ pada taraf nyata 5\% dan apabila hasilnya berpengaruh nyata maka dilanjutkan dengan uji tDunnet pada taraf nyata $5 \%$ menggunakan aplikasi SAS portable 9.1.3.

\section{HASIL DAN PEMBAHASAN}

\section{Kondisi Umum}

Yayasan Bina Sarana Bakti berlokasi di Jl. Gandamanah No.74, Kelurahan Tugu Selatan, Kecamatan Cisarua, Kabupaten Bogor. Letak geografis YBSB berada pada $6^{\circ} 41^{\prime} 17^{\prime \prime}$ LS dan $106^{\circ} 57^{\prime} 00^{\prime \prime}$ BT. Ketinggian wilayah disekitar YBSB yaitu $850 \mathrm{~m}$ diatas permukaan laut (dpl) dengan temperatur rata-rata sekitar $20^{\circ} \mathrm{C}$ sampai $22^{\circ} \mathrm{C}$, temperatur maksimal $27^{\circ} \mathrm{C}$ dan temperatur minimal $17^{\circ} \mathrm{C}$. Lama penyinaran matahari ketika musim kemarau mencapai 12 jam, namun saat musim hujan penyinaran matahari bisa berlangsung sekitar 4 sampai 6 jam saja.

YBSB memiliki lahan dengan total luas \pm 14 ha yang terbagi menjadi kebun produksi PT dan kebun diklat. Kebun diklat terbagi menjadi empat blok yaitu kebun ASTI, kebun villa Merak, kebun blok A, dan kebun blok K1 dengan jumlah bedengan yang berbeda-beda pada masing-masing blok. Masing-masing unit produksi memiliki infrastruktur pendukung lainnya, seperti rumah kompos, gudang, tempat persemaian, bak tadah hujan, jalan antar bedeng, parit, serta jalan utama. Satu luasan lahan atau plot ditanami dengan beberapa macam komoditas. Saat ini, YBSB memproduksi 72 jenis sayuran dengan 20 komoditas utama dan 52 komoditas pendukung.

\section{Aspek Teknis}

\section{Pembenihan}

Benih caisim yang digunakan di YBSB merupakan benih lokal yang diproduksi sendiri oleh BSB. Benih di YBSB diproduksi dikebun Mendawai dan ruang penyimpanan benih memiliki suhu ruang $19^{\circ} \mathrm{C}$. Tanaman caisim yag dijadikan indukan merupakan tanaman yang dipilih berdasarkan sifat-sifat yang baik dan sesuai dengan kondisi tanah setempat.

\section{Pembibitan}

Pembibitan merupakan kegiatan awal yang dilakukan sebelum penanaman. Benih caisim tidak ditanam secara langsung di lapangan melainkan disemai terlebih dahulu dengan tujuan mengurangi presentase kegagalan tanam dan memperoleh pertumbuhan tanaman yang seragam. Penyemaian benih caisim dilakukan dengan dua cara yaitu dengan menggunakan soil block atau polybag. Media yang digunakan merupakan campuran antara tanah subur dengan pupuk matang dengan perbandingan 2:1. Tanah campuran yang telah disiapkan kemudian dimasukkan ke dalam polybag. Penyemaian menggunakan polybag perlu dibuat lubang tanam terlebih dahulu sedalam 2-3 cm. Berbeda halnya dengan soil block, tanah campuran tersebut diberi air hingga menjadi sedikit liat dan mudah untuk dibentuk, kemudian dimasukkan kedalam cetakan soil block dan dicetak. Penyemaian dengan menggunakan soil block tidak perlu diberi lubang tanam karena pada cetakan soil block sudah terdapat lubang kecil ditengah untuk menanam benih. Benih caisim dipindah tanam ke lapangan setelah bibit berumur 2-3 minggu atau daun telah berjumlah 3-4 helai.

\section{Pengolahan Lahan dan Penanaman}

Persiapan lahan yang dilakukan untuk penanaman caisim meliputi sanitasi lahan, aplikasi pupuk dasar, dan pengolahan lahan. Pemupukan dilakukan setelah bedengan bersih dari gulma. Pupuk dasar yang digunakan yaitu berupa pupuk organik yang berasal dari pupuk kandang ayam, kambing, serta rumput atau dedaunan yang telah melalui proses fermentasi. Aplikasi pupuk matang untuk caisim menggunakan dosis $30-50 \mathrm{~kg}$ per bedengan. Pupuk padat diaplikasikan ke bedengan dengan cara disebar secara merata ke seluruh bedengan. Pengolahan lahan yang dilakukan menggunakan teknik minimum tillage yaitu penggarpuan. Tujuan tanah diolah menggunakan garpu yaitu untuk menjaga struktur tanah tetap remah, melonggarkan pori-pori tanah, serta menjaga mikroorganisme tanah agar tetap hidup. Penggarpuan dilakukan dengan kemiringan sekitar $45^{\circ}$ sedalam $30 \mathrm{~cm}$. Jarak tanam caisim yang digunakan yaitu $20 \mathrm{~cm}$ x $20 \mathrm{~cm}$ dan dibuat lubang selebar 5-10 cm. Bibit caisim dimasukkan kedalam lubang kemudian ditutup dengan menggunakan tanah. Di Yayasan Bina Sarana Bakti terdapat dua jenis pola tanam yaitu monokultur dan polikultur. Pola tanam polikultur berarti tanaman caisim dikombinasikan dengan beberapa tanaman lain yang berbeda jenis dalam satu bedengan pada satu musim tanam. 


\section{Pemeliharaan}

Kegiatan pemeliharaan caisim di YBSB umumnya meliputi penyiraman, penyiangan gulma, pemulsaan, dan pemberian pupuk organik cair serta pengendalian OPT. Penyiraman merupakan faktor penting yang dapat mempengaruhi hasil produksi caisim di musim kemarau. Penyiraman biasanya dilakukan setiap sore hari (diatas jam 2 siang) dengan dosis 80-100 liter per bedengan. Namun, frekuensi dan dosis penyiraman dapat disesuaikan dengan kondisi dan kebutuhan tanaman. Penyiangan gulma biasanya dilakukan sekali pada setiap musim tanam saja. Pupuk organik cair (POC) merupakan pupuk susul berwujud cair yang berasal dari urin kelinci yang dicampur dengan beberapa bahan lain atau berasal dari air resapan kompos. POC diaplikasikan pada saat tanaman berumur 2 MST sampai dengan 1 minggu sebelum panen dengan dosis yang berbeda pada setiap minggunya. Dosis yang digunakan pada 2 MST yaitu 1:9, sedangkan pada umur 3 MST dosis yang digunakan yaitu 2:8. Aplikasi POC biasanya dilakukan pada pagi atau sore hari untuk menghindari penguapan dan juga efisiensi tenaga kerja karyawan.

Mulsa yang digunakan oleh petani di YBSB yaitu mulsa organik yang berasal dari dedaunan atau bagian tanaman lainnya yang dapat dimanfaatkan sebagai bahan penutup tanah. Tumbuhan yang dijadkan sebagai mulsa organik bermacam-macam contohnya daun kaliandra (Calliandra haematocephala), daun kipait atau paitan (Tithonia sp.), batang pohon pisang, dan rumput lunak. Mulsa dapat diaplikasikan setelah tanam atau saat tanaman berumur 1 MST. Bahan mulsa yang akan digunakan dicacah menjadi bagian yang lebih kecil kemudian disebar merata ke permukaan tanah dengan ketebalan $\pm 5 \mathrm{~cm}$ hingga seluruh permukaan tanah tertutup oleh bahan mulsa. Usaha pengendalian OPT yang diterapkan pada komoditas caisim yaitu kegiatan holistik dan preventif. Menurut beberapa ketua plot, tindakan kuratif tidak perlu dilakukan apabila tindakan holistik dan preventif sudah dilaksanakan secara optimal.

\section{Panen dan Pasca Panen}

Tanaman caisim dapat dipanen pada umur 2-4 MST atau 5-7 MSS pada umumnya. Ciri-ciri caisim yang layak panen yaitu lebar daun maksimal, tidak busuk, tidak berlubang atau sedikit berlubang, berwarna hijau segar, tinggi tanaman minimal $25-30 \mathrm{~cm}$, tidak bercabang dan tidak berbunga. Caisim dipanen dengan cara dicabut kemudian dipotong akarnya pada jarak $1 \mathrm{~cm}$ dari pangkal batang. Kemudian dilakukan perompesan sebanyak 2-3 daun yang tua, rusak, berlubang, atau busuk. Caisim yang telah dipanen kemudian diletakkan kedalam kontainer untuk menghindari kerusakan mekanis.

Caisim yang telah diletakkan di kontainer kemudian diangkut dan dibawa ke bagian pemasaran atau packing house. Kegiatan pascapanen yang dilakukan di pemasaran yaitu penimbangan, pembersihan, trimming atau perompesan, packing atau pengemasan, penyimpanan, dan pengangkutan. Perompesan atau trimming bertujuan untuk mempertahankan kualitas produk dengan cara membuang atau memotong bagian daun yang tua, rusak, atau busuk. Meskipun perompesan sudah dilakukan di kebun, perompesan tetap dilakukan kembali di pemasaran. Hal ini dilakukan karena belum tentu hasil produk yang telah dirompes di kebun telah sesuai dengan standar mutu pasar yang telah ditentukan sehingga perlu dilakukan perompesan kembali. Caisim yang telah selesai dirompes dikemas menggunakan plastik polos berukuran 25 $\mathrm{cm}$ x $45 \mathrm{~cm}$ untuk dikirim ke agen. Kemudian bagian atas plastik direkatkan dengan menggunakan alat perekat atau sealer dengan jarak $\pm 5 \mathrm{~cm}$ dari atas plastik. Pengemasan bertujuan untuk mempermudah proses pengangkutan dan pendistribusian serta menjaga produk dari kerusakan.

\section{Pengaruh Perlakuan Mulsa Organik terhadap Fase Vegetatif Tanaman Caisim}

Hasil pengamatan menunjukkan bahwa perlakuan ketiga jenis mulsa tidak memberikan pengaruh nyata terhadap peubah yang diamati yaitu tinggi tanaman, jumlah daun, panjang daun, dan lebar daun (Tabel 1). Pemulsaan selain bertujuan untuk menjaga kelembaban dan memperkecil fluktuasi suhu tanah, juga dapat

Tabel 1. Hasil rekapitulasi sidik ragam peubah fase vegetatif komoditas caisim

\begin{tabular}{lrccc}
\hline No & \multicolumn{1}{c}{ Keubah } & F hit & Pr $>$ F & KK $(\%)$ \\
\hline 1 Tinggi tanaman 1 MSP & 10.40 & $1.08^{\text {th }}$ & 0.4269 & 19.66 \\
2 Tinggi tanaman 2 MSP & 47.35 & $2.18^{\text {th }}$ & 0.1916 & 15.57 \\
3 Tinggi tanaman 3 MSP & 62.89 & $4.42^{\text {th }}$ & 0.0579 & 10.86 \\
4 Jumlah daun 1 MSP & 0.23 & $0.29^{\text {th }}$ & 0.8304 & 17.55 \\
5 Jumlah daun 2 MSP & 2.23 & $1.74^{\text {th }}$ & 0.2571 & 14.45 \\
6 Jumlah daun 3 MSP & 3.90 & $3.70^{\text {th }}$ & 0.0810 & 11.79 \\
7 Panjang daun 1 MSP & 6.22 & $1.90^{\text {th }}$ & 0.2304 & 19.48 \\
8 Panjang daun 2 MSP & 11.32 & $2.12^{\text {tn }}$ & 0.1993 & 13.43 \\
9 Panjang daun 3 MSP & 12.88 & $1.43^{\text {th }}$ & 0.3228 & 15.41 \\
10 Lebar daun 1 MSP & 3.42 & $1.82^{\text {th }}$ & 0.2434 & 21.01 \\
11 Lebar daun 2 MSP & 5.65 & $2.19^{\text {tn }}$ & 0.1898 & 14.35 \\
12 Lebar daun 3 MSP & 6.62 & $2.99^{\text {th }}$ & 0.1173 & 11.99 \\
\hline K
\end{tabular}

Keterangan : ** = berpengaruh sangat nyata pada taraf $1 \% ; *=$ berpengaruh nyata pada taraf $5 \%$; tn $=$ tidak berpengaruh nyata berdasarkan hasil uji F. 
menyumbang unsur hara kedalam tanah yang berguna untuk menjaga atau meningkatkan kesuburan tanah akibat pelapukan bahan mulsa organik tersebut. Suryani (2007) menyatakan bahwa bahan organik yang berasal dari tumbuhan mengalami proses dekomposisi lebih lama, khususnya tumbuhan yang mengandung lignin lebih banyak. Pengamatan ini berlangsung dalam waktu yang relatif singkat (3 minggu) sehingga bahan organik yang lapuk belum bisa cukup untuk menambah unsur hara dalam tanah dan membantu meningkatkan produktivitas tanaman.

Tinggi tanaman diukur dari pangkal batang hingga titik tumbuh tertinggi pada setiap minggu sampai dengan menjelang panen. Meskipun tidak berbeda nyata, terdapat kecenderungan pada peubah tinggi tanaman. Pengamatan tinggi tanaman pada tanaman contoh menunjukkan bahwa caisim yang diberi perlakuan mulsa Tithonia sp. memiliki hasil yang lebih tinggi dibandingkan dengan perlakuan yang lain (Tabel 2).

Tabel 2. Nilai tengah perlakuan jenis mulsa terhadap peubah tinggi tanaman umur 1-3 MSP komoditas caisim

\begin{tabular}{llllcc}
\hline \multirow{2}{*}{$\begin{array}{c}\text { Tinggi } \\
\text { No }\end{array}$ Tanaman } & \multicolumn{4}{c}{ Jenis Mulsa } \\
\cline { 2 - 6 }$n$ & Kontrol Rumput & $\begin{array}{c}\text { Gedebong } \\
\text { Pisang }\end{array}$ & $\begin{array}{c}\text { Daun } \\
\text { Tithonia } \text { sp. }\end{array}$ \\
\hline 1 & $1 \mathrm{MSP}$ & $15.86 \mathrm{a}$ & $13.86 \mathrm{a}$ & $15.22 \mathrm{a}$ & $18.31 \mathrm{a}$ \\
2 & $2 \mathrm{MSP}$ & $27.82 \mathrm{a}$ & $28.24 \mathrm{a}$ & $27.81 \mathrm{a}$ & $35.89 \mathrm{a}$ \\
3 & $3 \mathrm{MSP}$ & $32.70 \mathrm{~b}$ & $31.58 \mathrm{~b}$ & $33.13 \mathrm{~b}$ & $41.54 \mathrm{a}$ \\
\hline
\end{tabular}

Keterangan : Angka yang sama pada baris dan kolom yang sama tidak berbeda nyata berdasarkan uji DMRT pada taraf $\alpha 5 \%$

Jumlah daun dihitung dengan menghitung jumlah daun yang telah terbuka sempurna. Pengamatan dilakukan setiap minggu sampai dengan menjelang panen. Hasil pengamatan menunjukkan bahwa tanaman yang diberi perlakuan mulsa Tithonia sp memiliki jumlah daun terbanyak dibandingkan dengan perlakuan lainnya, meskipun secara statistik tidak berbeda nyata (Tabel 3). Jumlah daun pada saat umur 3 MSP menunjukkan jumlah daun terendah terdapat

Tabel 3. Nilai tengah perlakuan jenis mulsa terhadap peubah jumlah daun umur 1-3 MSP komoditas caisim

\begin{tabular}{|c|c|c|c|c|}
\hline \multirow{2}{*}{${ }^{\mathrm{No}} \stackrel{\text { Jumlah }}{\text { Daun }}$} & \multicolumn{4}{|c|}{ Jenis Mulsa } \\
\hline & Kontrol & Rumput & $\begin{array}{c}\text { Gedebong } \\
\text { Pisang }\end{array}$ & $\begin{array}{c}\text { Daun } \\
\text { Tithonia } \mathrm{sp}\end{array}$ \\
\hline 11 MSP & $5.13 \mathrm{a}$ & $5.03 \mathrm{a}$ & $4.70 \mathrm{a}$ & $5.37 \mathrm{a}$ \\
\hline $22 \mathrm{MSP}$ & $7.50 \mathrm{a}$ & $7.83 \mathrm{a}$ & $6.97 \mathrm{a}$ & $9.00 \mathrm{a}$ \\
\hline 33 MSP & $8.30 \mathrm{ab}$ & $8.37 \mathrm{ab}$ & $7.77 \mathrm{~b}$ & $10.36 \mathrm{a}$ \\
\hline
\end{tabular}

Keterangan : Angka yang sama pada baris dan kolom yang sama tidak berbeda nyata berdasarkan uji DMRT pada taraf $\alpha 5 \%$ pada perlakuan gedebong pisang yaitu 7-8 helai daun, sedangkan jumlah daun tertinggi terdapat pada perlakuan mulsa Tithonia sp yaitu 10-11 helai daun.

Panjang daun setiap tanaman diukur pada satu daun terluas pada setiap tanaman yang diukur dari pangkal daun hingga ke ujung daun. Hasil pengamatan panjang daun pada umur 1 dan 2 MSP memperlihatkan bahwa panjang daun tanaman kontrol lebih tinggi dibandingkan dengan tanaman yang diberi perlakuan mulsa rumput, namun pada umur 3 MSP panjang daun tanaman kontrol lebih tinggi dari perlakuan mulsa rumput dan gedebong pisang. Sementar itu, panjang daun terbesar terdapat pada tanaman dengan perlakuan mulsa Tithonia sp. (Tabel 4).

Tabel 4. Nilai tengah perlakuan jenis mulsa terhadap peubah panjang daun umur 13 MSP komoditas caisim

\begin{tabular}{llrrrc}
\hline \multirow{2}{*}{$\begin{array}{c}\text { No Panjang } \\
\text { Daun }\end{array}$} & \multicolumn{4}{c}{ Jenis Mulsa } \\
\cline { 2 - 6 } & Kontrol Rumput & $\begin{array}{c}\text { Gedebong } \\
\text { Pisang }\end{array}$ & $\begin{array}{c}\text { Daun } \\
\text { Tithonia } \text { sp. }\end{array}$ \\
\hline 1 & $1 \mathrm{MSP}$ & $8.62 \mathrm{a}$ & $8.07 \mathrm{a}$ & $9.08 \mathrm{a}$ & $11.35 \mathrm{a}$ \\
2 & $2 \mathrm{MSP}$ & $16.51 \mathrm{a}$ & $15.72 \mathrm{a}$ & $16.57 \mathrm{a}$ & $20.07 \mathrm{a}$ \\
3 & $3 \mathrm{MSP}$ & $18.82 \mathrm{a}$ & $17.81 \mathrm{a}$ & $18.67 \mathrm{a}$ & $22.48 \mathrm{a}$ \\
\hline
\end{tabular}

Keterangan : Angka yang sama pada baris dan kolom yang sama tidak berbeda nyata berdasarkan uji DMRT pada taraf $\alpha 5 \%$

Lebar daun setiap tanaman diukur pada satu daun terluas pada setiap tanaman dengan cara mengukur bagian daun terlebar. Pengamatan lebar daun menunjukkan hasil yang berbeda setiap minggunya (Tabel 5). Lebar daun terkecil pada umur 1 MSP terdapat pada tanaman dengan perlakuan mulsa rumput. Tanaman yang diberi perlakuan mulsa gedebong pisang memeiliki lebar daun yang terkecil pada umur 2 MSP, sedangkan pada umur 3 MSP tanaman yang tidak diberi perlakuan mulsa memiliki lebar daun terkecil. Akan tetapi, secara umum dari keempat perlakuan mulsa tanaman yang memiliki lebar daun terbesar terdapat pada tanaman yang diberi perlakuan mulsa Tithonia sp.

Tabel 5. Nilai tengah perlakuan jenis mulsa terhadap peubah lebar daun umur 1-3 MSP komoditas caisim

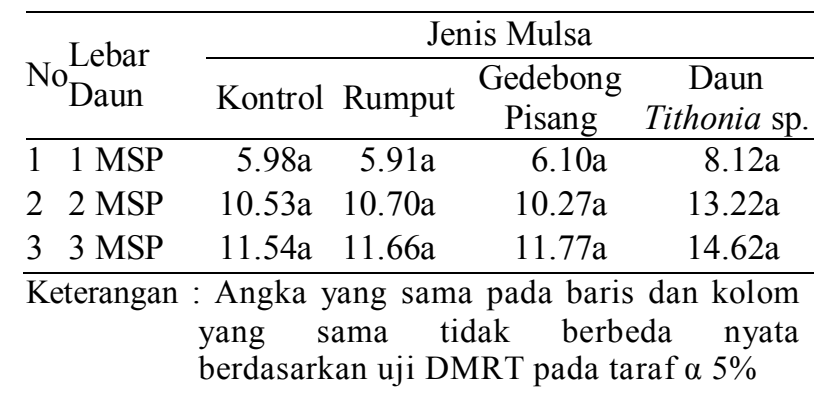




\section{Pengaruh Perlakuan Mulsa Organik terhadap Hasil dan Komponen Hasil Tanaman Caisim}

Berdasarkan uji $\mathrm{F}$ pada analisis ragam, perlakuan jenis mulsa berpengaruh nyata terhadap bobot akar, bobot rompesan, jumlah daun rusak akibat OPT (Tabel 6). Bobot daun rusak akibat OPT dan populasi gulma menunjukkan pengaruh sangat nyata terhadap perlakuan keempat jenis mulsa. Sementara itu, hasil analisis menunjukkan pengaruh tidak nyata terhadap peubah lainnya.

Setelah dilakukan uji lanjut DMRT pada taraf nyata 5\%, perlakuan jenis mulsa Tithonia sp. memberikan pengaruh nyata lebih tinggi dibandingkan dengan perlakuan mulsa lainnya pada peubah bobot akar (Tabel 7). Lestari (2016) mengatakan bahwa kandungan unsur $\mathrm{K}$ dalam Tithonia sp. cukup tinggi yaitu sekitar $5.75 \%$ yang berperan dalam merangsang perkembangan akar dan mengatur serapan hara, sehingga bobot akar pada perlakuan mulsa Tithonia sp. lebih tinggi dibandingkan dengan perlakuan lainnya. Selain itu, bobot rompesan, jumlah daun yang terserang daun akibat OPT dan bobot daun yang rusak akibat OPT juga memiliki hasil lebih tinggi dibandingkan perlakuan lainnya. Petak contoh yang tidak diberi perlakuan mulsa memiliki jumlah populasi gulma lebih tinggi dibandingkan dengan petakan lain yang diberi perlakuan mulsa. Aplikasi mulsa dapat mengendalikan pertumbuhan gulma di dalam bedengan karena pemberian mulsa mempersempit ruang tumbuh pada gulma sehingga biji gulma sulit berkecambah atau bahkan tidak tumbuh (Setyorini dan Hartatik, 2015). Akan tetapi, tanaman dengan mulsa Tithonia sp. memiliki jumlah populasi gulma lebih tinggi dibandingkan dengan mulsa rumput dan mulsa gedebong pisang. Hal ini dapat disebabkan karena mulsa Tithonia sp. lebih mudah terdekomposisi, sementara itu aplikasi mulsa hanya dilakukan sekali dalam satu musim tanam sehingga pada bedengan perlakuan mulsa Tithonia sp. terdapat ruang tumbuh yang lebih luas bagi gulma dibandingkan dengan perlakuan lainnya.

Tabel 6 . Hasil rekapitulasi sidik ragam perlakuan jenis mulsa terhadap hasil dan komponen hasil komoditas caisim

\begin{tabular}{|c|c|c|c|c|c|}
\hline No & Peubah & KT & F hit & $\operatorname{Pr}>F$ & KK (\%) \\
\hline 1 & Bobot brangkasan & 1429.2600 & $4.70^{\text {tn }}$ & 0.0512 & 29.63 \\
\hline 2 & Bobot akar & 1.9218 & $5.39^{*}$ & 0.0387 & 26.09 \\
\hline 3 & Bobot per tanaman & 2.7875 & $4.36^{\text {th }}$ & 0.0594 & 7.58 \\
\hline 4 & Jumlah daun rompesan & 0.8744 & $2.16^{\text {th }}$ & 0.1940 & 17.79 \\
\hline 5 & Bobot daun rompesan & 1.7356 & $6.52 *$ & 0.0257 & 8.46 \\
\hline 6 & Jumlah daun rusak mekanis & 0.0067 & $2.67^{\text {th }}$ & 0.1416 & 3.48 \\
\hline 7 & Bobot daun rusak mekanis & 0.2719 & $2.39^{\text {tn }}$ & 0.1671 & 21.17 \\
\hline 8 & Jumlah daun rusak akibat OPT & 0.1075 & $8.60^{*}$ & 0.0136 & 12.08 \\
\hline 9 & Bobot daun rusak akibat OPT & 0.8600 & 17.49 ** & 0.0023 & 11.08 \\
\hline 10 & Jumlah daun tua & 0.0097 & $0.06^{\mathrm{tn}}$ & 0.9811 & 20.47 \\
\hline 11 & Bobot daun tua & 0.1833 & $0.14^{\mathrm{tn}}$ & 0.9323 & 24.94 \\
\hline 12 & Populasi gulma & 167228.0000 & $272.75 * *$ & $<.0001$ & 10.48 \\
\hline
\end{tabular}

Keterangan : ${ }^{* *}=$ berpengaruh sangat nyata pada taraf nyata $1 \%$; $*=$ berpengaruh nyata pada taraf $5 \%$; $\mathrm{tn}=$ tidak berpengaruh nyata berdasarkan hasil uji $\mathrm{F}$

Tabel 7. Nilai tengah perlakuan jenis mulsa terhadap hasil dan komponen hasil komoditas caisim

\begin{tabular}{llcccc}
\hline No & Koubah & Kontrol & & Mulsa Rumput & Mulsa Gedebong Pisang Mulsa Daun Tithonia $\mathrm{sp}$. \\
\hline 1 & Bobot brangkasan & $51.88 \mathrm{~b}$ & $38.42 \mathrm{~b}$ & $55.37 \mathrm{ab}$ & $89.69 \mathrm{a}$ \\
2 & Bobot akar & $1.93 \mathrm{~b}$ & $1.66 \mathrm{~b}$ & $2.11 \mathrm{~b}$ & $3.46 \mathrm{a}$ \\
3 & Bobot per tanaman & $10.27 \mathrm{ab}$ & $9.57 \mathrm{~b}$ & $10.47 \mathrm{ab}$ & $11.87 \mathrm{a}$ \\
4 & Jumlah daun rompesan & $3.27 \mathrm{a}$ & $3.07 \mathrm{a}$ & $3.68 \mathrm{a}$ & $4.29 \mathrm{a}$ \\
5 & Bobot daun rompesan & $5.80 \mathrm{~b}$ & $5.77 \mathrm{~b}$ & $5.60 \mathrm{~b}$ & $7.23 \mathrm{a}$ \\
6 & Jumlah daun rusak mekanis & $1.40 \mathrm{a}$ & $1.43 \mathrm{a}$ & $1.40 \mathrm{a}$ & $1.50 \mathrm{a}$ \\
7 & Bobot daun rusak mekanis & $1.40 \mathrm{a}$ & $1.53 \mathrm{a}$ & $1.40 \mathrm{a}$ & $2.03 \mathrm{a}$ \\
8 & Jumlah daun rusak akibat OPT & $0.80 \mathrm{~b}$ & $0.90 \mathrm{~b}$ & $0.80 \mathrm{~b}$ & $1.20 \mathrm{a}$ \\
9 & Bobot daun rusak akibat OPT & $1.70 \mathrm{~b}$ & $1.80 \mathrm{~b}$ & $1.70 \mathrm{~b}$ & $2.80 \mathrm{a}$ \\
10 & Jumlah daun tua & $2.03 \mathrm{a}$ & $2.10 \mathrm{a}$ & $2.07 \mathrm{a}$ & $1.97 \mathrm{a}$ \\
11 & Bobot daun tua & $4.53 \mathrm{a}$ & $4.60 \mathrm{a}$ & $4.30 \mathrm{a}$ & $4.90 \mathrm{a}$ \\
12 & Populasi gulma & $588.00 \mathrm{a}$ & $100.33 \mathrm{c}$ & $99.33 \mathrm{c}$ & $157.00 \mathrm{~b}$ \\
\hline
\end{tabular}

Keterangan : Angka yang sama pada baris dan kolom yang sama tidak berbeda nyata berdasarkan uji DMRT pada taraf $\alpha 5 \%$ 


\section{KESIMPULAN}

Pemberian mulsa tidak berpengaruh nyata terhadap tinggi tanaman, jumlah daun, panjang daun, dan lebar daun namun perlakuan pemberian mulsa Tithonia sp. cenderung menunjukkan hasil tertinggi dibandingkan dengan kontrol dan perlakuan mulsa lainnya. Pemberian mulsa baik mulsa rumput, mulsa kedebong pisang, maupun mulsa Tithonia sp., secara nyata mampu menekan populasi gulma dalam bedengan.

\section{DAFTAR PUSTAKA}

[AOI] Aliansi Organik Indonesia. 2015. Statistik Pertanian Organik Indonesia 2015. AOI, Jakarta.

Jahroh, S. 2010. Organic farming development in indonesia: lessons learned from organic farming in west java and north sumatra. ISDA 2010: 1-11.

[Kementan] Kementrian Pertanian. 2015. Statistik konsumsi pangan 2015. http://epublikasi. setjen.pertanian. go.id/perstatistikan/163- statistik/statistik-konsumsi/370-statistikkonsumsi-pangan-2015. [11 Desember 2016].

Lestari, S.A.D., 2016. Pemanfaatan paitan (Tithonia diversifolia) sebagai pupuk organik pada tanaman kedelai. J. Iptek Tanaman Pangan. 11(1): 49-56.

Setyorini, D., W. Hartatik. 2015. Pengelolaan lahan dan budidaya sayuran dalam sistem pertanian organik. Sistem Pertanian Organik Mendukung Produktivitas Lahan Berkelanjutan. IAARD Press, Jakarta.

Suryani, A. 2007. Perbaikan tanah media tanaman jeruk dengan berbagai bahan organik dalam bentuk kompos. [Tesis]. Institut Pertanian Bogor.

Yulianingrum, H., E. Supraptomo, P. Setyanto. 2016. Pengaruh pemberian mulsa jerami padi terhadap kelimpahan gulma dan pertumbuhan tanaman tomat (Solanum lycopersicum). Prosiding Konser Karya Ilmiah. Agustus 2016. 